\title{
THE GROWTH OF INTERDISCIPLINARY RESEARCH AND THE INDUSTRIAL STRUCTURE OF THE PRODUCTION OF LEGAL IDEAS: A REPLY TO JUDGE EDWARDS
}

\author{
George L. Priest*
}

Judge Edwards' lively essay ${ }^{1}$ declaims what he regards as the increasing disjunction between the substance of modern legal education and scholarship and the needs and interests of the judiciary and the practicing bar. According to Judge Edwards, law schools and law firms are moving in opposite directions. Law schools have increasingly abandoned real world legal problems in favor of abstract interdisciplinary theory, with a consequent diminution in their contribution toward solving problems faced by the judiciary. At the same time, law firms are becoming increasingly profit oriented, without regard to pursuing broader social interests. To combat these developments, Judge Edwards proposes that legal education be substantially reformed: he proposes greater production of "practical" - by which he means more purely doctrinal and noninterdisciplinary - scholarship, greater credit to practical scholars, more explicitly doctrinal teaching, and greater attention to the teaching of legal ethics, defined not simply as mastery of the canons, but as the understanding of the law as an instrument to promote the public interest.

Judge Edwards views me as a particularly pernicious advocate of the developments he seeks to reverse. In talks given some years ago, I described the increasing influence upon legal scholarship and teaching of interdisciplinary research in the social sciences and humanistic studies - philosophy and interpretation. I described the modern law school as itself coming to resemble a university, with a curriculum consisting of minigraduate courses in applied economics, social theory, and political science. ${ }^{2}$ To me, these developments implied, first, a

* John M. Olin Professor of Law and Economics, Yale Law School. - Ed. Unintentionally, but undoubtedly, this essay draws on remarks of my colleague John H. Langbein at the 1993 Yale Law School graduation. He is not responsible, however, for any of the conclusions.

1. Harry T. Edwards, The Growing Disjunction Between Legal Education and the Legal Profession, 91 Mich. L. REv. 34 (1992).

2. George L. Priest, Social Science Theory and Legal Education: The Law School as University, 33 J. LEGAL EDUC. 437 (1983). 
challenge to the distinctive significance of law as a subject of study and, second, an increasing division between the academy and the bar. ${ }^{3}$ Unlike Judge Edwards, however, I applauded the trend.

Judge Edwards' opposition to this work could not be stronger. $\mathrm{He}$ explicitly rejects the "graduate school' model of legal education," which he attributes to me. ${ }^{4} \mathrm{He}$ criticizes what he regards as my "arrogant, antidoctrinal bias."' He describes what he regards as my "disdain for law practice" as "deplorable."6 Moreover, he concludes that arguments such as mine, which seem to encourage the growing disjunction between legal education and the legal profession, are "utterly specious."7

The article of mine most criticized by Judge Edwards is now over a decade old ${ }^{8}$ and, upon rereading it, I can appreciate the source of Judge Edwards' dismay. Though I believe that the article accurately describes current developments in legal education, it does not adequately explain their source or the determinants of the relationship between modern legal scholarship and the problems facing the judiciary and the bar. The article, and a successor, ${ }^{9}$ focus, I now believe simplistically, upon participants in the dissemination of legal ideas who most clearly differ - advanced theoreticians and the practicing bar - without any explanation of the participants or institutions that intermediate between them. In addition - though this is a point that Judge Edwards did not criticize - the article contains an evaluation of the importance of legal study that modern events have demonstrated to me to be a severe underestimate. ${ }^{10}$

This brief response will attempt to repair these various deficiencies, though only in part because of the difficulty of the subject. It will try to explain more fully the rise of interdisciplinary legal research and will sketch the broader structure of the production and dissemination of new ideas about law and the legal system. The relationship between legal education and legal practice implicates an understanding of the "market" for legal ideas. To describe ideas as the subject of a "market," of course, has become conventional. In my view, however, the

3. George L. Priest, The Increasing Division Between Legal Practice and Legal Education, 37 BUFF. L. REV. 681 (1989).

4. Edwards, supra note 1, at 40.

5. Id. I am slightly comforted that, at a later point, Judge Edwards describes the approach of another author as "considerably more arrogant" than mine. Id. at 52 n.53.

6. Id. at 52 .

7. Id. at 76.

8. Priest, supra note 2.

9. Priest, supra note 3.

10. See infra note 35. 
market metaphor most typically distorts our understanding of the issue, because few of the typical characteristics of economic markets are present in the dissemination of ideas. This essay will try to approach a description of a market, nevertheless, by illustrating similarities between the production of legal ideas within law schools and the bar and the production of intellectual property in more familiar industrial contexts. The description will be far from comprehensive, but it will suggest that the alleged "disjunction" between legal education and practice, the focus of Judge Edwards' essay as well as of my own earlier writing, does not adequately account for the broader process at work. The essay will also suggest that many of the developments in modern legal education that Judge Edwards so severely criticizes ${ }^{11}$ actually support, rather than conflict with, the broader values that he espouses.

Part I attempts to explain more fully than did my earlier articles why legal scholarship and education are increasingly dominated by interdisciplinary studies in contrast to the doctrinal, practical work that Judge Edwards prefers. Part II will address the alleged "disjunction" between the legal academy and the bar by beginning a description of the structure of production and dissemination of legal ideas. Finally, Part III will address Judge Edwards' proposals more specifically.

\section{The Realist INFLUence on Law and THE Steadily INCREASING IMPORTANCE OF INTERDISCIPLINARY STUDY}

There is little question that the most significant development in American law of the past century has been the realist revolution leading to the broader understanding of law and legal doctrine as instruments of social policy. Following the realists, it is no longer sufficient to defend legal doctrine on the mere grounds that a rule is a rule, or that the doctrine derives from time immemorial. Rather, it is necessary to show that the doctrine has a beneficial effect on the society, is an expression of an important public value, or otherwise serves the public interest. I shall not defend here this characterization of the impact of realism; it is hardly controversial. I do not believe that Judge Edwards would disagree. Indeed, this approach toward the law is an important component of Judge Edwards" advocacy of "ethical

11. This essay generally ignores developments at the Harvard Law School, the subject of much of Judge Edwards' criticism. See Edwards, supra note 1, at 37 (describing the "recent fiasco"); see also id. at 39-40, 51 n.52. While the Harvard situation may be explained in part by the process I discuss, it may also be sui generis. 
practice."12

This change in the understanding of the role of law, however, had important implications for legal scholarship and teaching. Both had to be redirected necessarily toward illumination of the functions and philosophical underpinnings of the law. Judge Edwards himself describes the change: the prerealist Langdellian view that a student could understand the law from no more than the texts of then-dominant cases is no longer adequate. ${ }^{13}$ Instead, it is necessary today, in Judge Edwards' words, to 'integrate theory with doctrine, because both are relevant to the practitioner and governmental decisionmaker."14

Nevertheless, although Judge Edwards seems to support strongly the greater attention legal academics give to the role of law in fulfilling social values or serving the public interest, much of what he criticizes in modern legal scholarship and education is the direct effect of the postrealist change in approach. First, the realist revolution challenges law and the legal system as distinctive social institutions. If a legal rule is viewed as an instrument of social policy or as an expression of public values, then it must be compared with other available instruments for the achievement of similar ends. The distinctive position of law necessarily diminishes. Secondly, the realist revolution challenges the insularity and uniqueness of legal reasoning and analysis. If a legal rule is viewed as an instrument for imparting a beneficial societal effect, expressing a value, or otherwise achieving the public interest, it is surely as important to study the societal effect, the value, and the definition of the public interest as it is to study the legal mechanism employed to achieve it. ${ }^{15}$

Most importantly, given the realist revolution, greater interdisciplinary study of law and the legal system follows directly. Judge Edwards sharply criticizes the rise of interdisciplinary "law-and" scholarship and teaching in favor of greater attention to legal doc-

12. Judge Edwards defines "ethical" practice variously: Id. at 66 ("concern for the public interest"); id. at 67 ("to advance somie causes that he or she believes to be just"); id. at 69 ("to view his or her legal knowledge ... as a set of norms"); id. at 72 ("When I practiced law ... we felt the work was . . . valuable to society . . . "); id. at 73 (" '[E]thical graduates' . . will . . . practice law in a manner that serves the public interest."). See generally Harry T. Edwards, $A$ Lawyer's Duty to Serve the Public Good, 65 N.Y.U. L. REv. 1148 (1990).

13. Edwards, supra note 1, at 44.

14. Id.

15. Judge Edwards is particularly scathing in his references to a passage of mine indicating the importance to a person interested in law's effects on behavior of studying behavior, rather than simply the law. Id. at 52 (citing Priest, supra note 2, at 439). Judge Edwards somehow interprets this passage as evidencing "disdain for law practice," which he finds to be "deplorable." Id. I regret that the passage could be misinterpreted this way, in particular, because I do not disdain law practice. 
trine. ${ }^{16}$ But legal doctrine alone cannot determine effects or define either values or the public interest. For example, my essay criticized by Judge Edwards addressed law and the social sciences. ${ }^{17}$ Among other challenges the realists posed was the determination of the actual societal effects of a legal rule or legal institution. All would surely agree that it is important to the definition and justification of the law to study such effects. To understand the actual effects of law on society, however, it is essential to go beyond the law and legal doctrine itself. The law itself possesses neither an internal metric nor a methodology for determining effects. Obviously, the most promising avenues for studying the effects of the law are social sciences that have been developed to study effects in other contexts: economics, sociology, psychology. Again, attention to legal doctrine alone will not provide answers to the question. ${ }^{18}$

The rise of other forms of interdisciplinary study in legal scholarship and teaching is similar. To the extent that it is important to understand the legal system as one of society's political institutions, it is important to invoke broader learning about politics and political institutions, for example, with the study of political science. Again, a focus on legal doctrine alone will be insufficient since legal doctrine, on its face, is unlikely to reveal political infiuence or consequence. Similarly, when law is viewed as an expression of public values, it is important to study the content of those values and, thus, important to develop an understanding of philosophy and social theory. Legal doctrine may reflect values, but it cannot explain or justify those values, nor can it illustrate how those values might best be extended.

Of course, concerns in legal scholarship and teaching about effects, values, or the definition of the public interest were not unknown prior to the realists. In my area, tort law, for example, I have elsewhere described Francis Bohlen's "benefit" theory, Jeremiah Smith's "cost internalization" point, and Fleming James' ideas about insurance as reflecting a partial economic basis. ${ }^{19}$ Similarly, one can relate nine-

16. Id. at 56-59.

17. Priest, supra note 2.

18. Judge Edwards apparently understands the discipline of law and economics as relevant chiefly for determining whether a legal outcome is efficient. Edwards, supra note 1, at 47 ; id. at 49 ("The law-and-economics scholar, just like the economist, uses economic analysis to assess 'efficiency." "). This highly crabbed view is surely not reflective of the broader impact of law and economics on legal scholarship and teaching. At another point, Judge Edwards admits that there are other forms of law-and-economics research. See id. at $47 \mathrm{n} .38$. Nevertheless, he does not describe what these might be or what role they might have in improving legal understanding or law reform.

19. George L. Priest, The Invention of Enterprise Liability: A Critical History of the Intellectual Foundations of Modern Tort Law, 14 J. LEGAL STUD. 461 (1985). 
teenth-century tort law doctrine to nascent conceptions of corrective justice. What is different about modern legal scholarship, however, is the greater rigor of the analysis, indeed, the exponentially greater rigor. My colleague Guido Calabresi's The Costs of Accidents ${ }^{20}$ vastly enriched Fleming James' ideas about insurance. The voluminous work of William M. Landes and Richard A. Posner, in turn, pressed forward one aspect of Calabresi's analysis. ${ }^{21}$ Many modern economists have attempted further advances. ${ }^{22}$ Similarly, modern legal philosophers have dramatically refined earlier vague incantations of social values. ${ }^{23}$ Judge Edwards may decry the increase of interdisciplinary "law and" scholarship in contrast to doctrinal research, but this research has increased and refined our understanding of the law far beyond what generations of doctrinalists had achieved.

There are additional reasons for the increasing importance of interdisciplinary study in modern legal scholarship and teaching. Here it is useful to refer to a distinction Judge Edwards has introduced in describing the cases that come before him as a federal appellate judge. In his essay on legal education and, more extensively, in other writings, ${ }^{24}$ Judge Edwards distinguishes three types of cases: "Easy" cases are those in which the pertinent rules are unambiguous and their application to the case clear. "Hard" cases are those for which there are decent arguments for both sides, though one can readily determine a resolution. In contrast, "very hard" cases are those in which "after reviewing the record and all the pertinent legal materials ... the competing arguments drawn from those sources are equally strong. . . . [A] fair application of the law to the facts leaves [the judge] in equipoise ...."25 Judge Edwards estimates that, in a given year, fifty percent of the cases he faces are easy; thirty-five to forty-five percent,

20. Guido Calabresi, The Costs of Accidents (1970).

21. For as close a summary of this work as possible, see William M. LANDES \& Richard A. POSNER, THE ECONOMIC STRUCTURE OF TORT LAW (1987).

22. See, e.g., Steven Shaveli, Economic Analysis of Accident Law (1987).

23. See, e.g., Emest J. Weinrib, Legal Formalism: On the Immanent Rationality of Law, 97 YALE L.J. 949 (1988).

24. See Edwards, supra note 1, at 44; Harry T. Edwards, The Judicial Function and the Elusive Goal of Principled Decisionmaking, 1991 Wisc. L. REv. 837, 856-63; Harry T. Edwards, The Role of a Judge in Modern Society: Some Reflections on Current Practice in Federal Appellate Adjudication, 32 ClEv. ST. L. REv. 385, 389-402 (1983-1984) [hereinafter Edwards, The Role of a Judge].

25. Edwards, The Role of a Judge, supra note 24, at 390 . Of course, evaluating cases according to the difficulty of resolution need not be constrained to three categories. An economist would imagine the existence of a continuum. See George L. Priest \& Benjamin Klein, The Selection of Disputes for Litigation, 13 J. LEGAL STUD. 1 (1984) (discussing economic determinants of the difficulty of cases that reach trial or appeal); George L. Priest, Selective Characteristics of Litigation, 9 J. LEGAL STUD. 399 (1980). 
hard; and five to fifteen percent, very hard. ${ }^{26}$

Both legal scholarship and education are directed toward the analysis of what Judge Edwards regards as "very hard" cases or problems. It is not surprising, of course, that legal scholarship should address "very hard" cases, and it is difficult to believe that Judge Edwards would disapprove of the priority. Because there are no clear or obvious resolutions to such cases, they provide the greatest opportunity for scholarly contribution to the public interest. In addition, such cases often implicate public issues of high significance. As a consequence, they are most likely to influence extensively the resolution of other disputes.

Cases that Judge Edwards defines as "very hard," however, are exactly the cases compelling the most serious interdisciplinary research. According to Judge Edwards' definition, legal doctrine alone cannot resolve these cases; there is compelling doctrinal support for both sides of the dispute. ${ }^{27}$ It follows necessarily, therefore, that a court must refer to some nondoctrinal source for a resolution. More precisely, in a postrealist world, cases with no clear or obvious resolutions are cases in which the societal effects of the legal ruling are hardest to determine, the social values implicated by the ruling in greatest conflict, or the public interest served by the resolution most difficult to define. It follows that these are the cases that compel the most rigorous interdisciplinary study.

Modern legal education also focuses on very hard cases, necessarily requiring increased interdisciplinary study in law schools. The dominant form of teaching in law schools is the case method, a method of studying not any case and not easy cases, but Judge Edwards' very hard cases. In contrast to the doctrinal teaching from treatises on the Continent and in England, class work in the United States consists of students immediately confronting the most difficult cases in the respective area of law. As in Judge Edwards' definition, cases chosen for the modern casebook present the greatest conflict between legal principles in which there are compelling arguments available for both sides. Indeed, such cases are often supplemented by hypotheticals that make the issue more difficult by pressing the conflicting principles even further than existing caselaw.

This form of teaching serves several plausible functions. First, it probably most effectively sharpens students' legal skills to confront them continuously with the most difficult issues of a field of law. Sec-

26. See id. at $389-90$.

27. Id. at 390. 
ond, it is an efficient technique for mastering doctrine. The case method places the student on a narrow, knife-edge ridge of conflicting doctrine, enabling a ready survey of the doctrinal landscape on either side below.

This pedagogical method, however, implicates the increasing importance of interdisciplinary study in law schools. Again by definition, the cases presented to students, like the very hard cases judges face, cannot be resolved by the invocation of legal doctrine alone. In the postrealist world, effects, values, or the public interest somehow defined must be called upon for a resolution. It follows necessarily that students as well as faculty must increasingly resort to interdisciplinary research and study.

This example suggests - as admittedly I did not in my earlier writings - that interdisciplinary teaching is not strictly antithetical to doctrinal teaching, a point I will expand in the next Part. Perhaps this is an unfortunate source of the disagreement between Judge Edwards and me. To focus principally on very hard cases for which there is no doctrinal resolution does not imply the neglect of doctrines controlling cases that are easy or merely hard. To the contrary, it is necessary to master the two or more lines of conflicting doctrine potentially controlling the dispute in order to appreciate what makes the case so very hard. Rather, for the resolution of very hard cases, again by definition, doctrine is not sufficient. In today's postrealist world, the judge, scholar, and student must increasingly turn to interdisciplinary research - in economics, sociology, philosophy, or social theory - to understand best how the law can advance the interests of society.

\section{The "MARKET" FOR LEgal IdeAS}

Judge Edwards' essay criticizes the increasing disjunction of the academy and the bar. ${ }^{28} \mathrm{My}$ earlier work had a similar focus, though I approved of the development. ${ }^{29}$ Both of us illustrate the point similarly, by contrasting the most advanced theoretical academics with the most practical judges and lawyers. This dichotomy between theorists and practitioners is engagingly vivid, but I am increasingly convinced that it inadequately describes our modern legal establishment.

Let us once more begin with Judge Edwards' categorization of cases as easy, hard, and very hard. Judge Edwards, it should be noted, does not oppose theory. His point, instead, is that easy cases can be resolved by doctrine alone, without theory; hard and very hard cases

28. Edwards, supra note 1.

29. Priest, supra note 3. 
by varying combinations of doctrine and theory. ${ }^{30}$ I fully accept his description. What determines the respective demands for doctrinal and theoretical research on the law? We have discussed that the impact of the realists has increased the need for theoretical research. Are other forces involved?

These remarks are no more than initial speculation on this issue. It is very likely, however, that broader economic forces affecting the legal profession influence the production of legal scholarship. For example, as is well known, the demand for legal services has increased substantially in the United States over the past seventy years, generating large increases in the number of lawyers, in lawyers' earnings, and in law school applications. ${ }^{31}$ Peter Pashigian shows that the number of lawyers in the United States more than doubled between 1920 and 1970.32 The number more than doubled again between 1970 and 1988.33 This occupational trend, of course, reflects an underlying increase in the volume of litigation, ${ }^{34}$ in the level of government regulation, and in the size of the economy as well as, more generally, a continued increase in the importance of law and our legal system to modern society. ${ }^{35}$

Even at the simplest level of analysis, the increase in the demand for and supply of lawyers will generate an increasing division of labor. This is hardly a controversial conclusion. It is obvious to any observer that the level of specialization among and within modern law firms has increased dramatically over the past decades.

The increasing specialization of legal practice is very likely to be accompanied by an increasing specialization of law-related research and scholarship. It is, of course, difficult to measure degrees of specialization in research, but the implication follows from the general principle of the division of labor. As the volume and diversity of the

30. Edwards, supra note 1 , at 44-45.

31. See B. Peter Pashigian, The Market for Lawyers: The Determinants of the Demand for and Supply of Lawyers, 20 J.L. \& EcoN. 53 (1977); Sherwin Rosen, The Market for Lawyers, 35 J.L. \& ECON. 215 (1992).

32. Pashigian, supra note 31 , at 54 tbl. 1 (counting judges among the total number of lawyers).

33. Bureau of the Census, U.S. Dept. of Commerce, Statistical Aastract of the UNITED STATES 192 tbl. 314 (112th ed. 1992).

34. For some evidence at the state court level, see George L. Priest, Private Litigants and the Court Congestion Problem, 69 B.U. L. ReV. 527 (1989).

35. In my essay on law and the social sciences, Priest supra note 2, I suggested that the importance of law and the legal system to a person interested in economics approximates the importance of industries such as oil or armament manufacture. Id. at 438 . I am now convinced that this represents a gross underestimate. The current abject position of the economies of the former Soviet and the Eastern European states, which can be attributed in important part to the absence of effective legal systems, suggests the far broader economic impact of the law. 
law become greater and the volume and diversity of legal materials become greater, there are greater returns or comparative advantage to specialization. The benefits of the division of labor imply greater specialization in both theoretical and doctrinal research as well as the emergence of a variety of intermediate specializations, which, according to Judge Edwards' categorization, will incorporate differing combinations of theory and doctrine.

There is some evidence that these developments are taking place. Judge Edwards and I have both noted that individuals who are chiefly practicing attorneys rather than full-time academics have increasingly dominated production of the doctrinal treatise. ${ }^{36}$ At the same time, of course, the scope of the typical legal treatise has changed dramatically. It is rare to observe a modern equivalent of the magisterial treatises, say, of Williston or Corbin encompassing what was then the entirety of contract law. ${ }^{37}$ Today, in their place are multiple treatises addressing increasingly detailed contract law subspecialties. Again, at the simplest analytical level, it should not be surprising that these texts are authored by individuals who are primarily practitioners. The returns from mastery of the details of these areas, and thus the comparative advantage, are likely to be far greater to a person working day by day, hour by hour on these problems than to an academic whose teaching touches at best one to two related cases per term.

Judge Edwards condemns the broader legal academy for abandoning the authorship of "practical" doctrinal treatises, invoking the contrary examples of Charles Alan Wright and Laurence Tribe. ${ }^{38}$ But his examples are actually proof of the point. First, the Wright and Miller and Tribe treatises differ substantially from the average modern treatise because of the much broader scope of their subjects, another illustration of modern specialization. Second, though Professors Wright and Tribe hold distinguished academic positions, on a metric, say, of relative proportion of time or income, it may be more accurate to regard them as principally practitioners rather than as theorists, though practitioners at a highly skilled and specialized level, of course.

Again, these remarks are no more than a sketch, but it is not implausible that there are similarities between the structure of production of legal ideas and the production of intellectual property in other

36. Id. at 437; cf. Edwards, supra note 1, at 36,49 n.44 (noting that legal academics are moving away from treatise writing). For Judge Edwards' broader advocacy of the academic production of treatises, see $i d$. at $42-57$.

37. Arthur L. Corbin, Corbin on Contracts (1950); Samuel Williston, A TreaTISE ON THE LAW OF CONTRACTS (1920).

38. Edwards, supra note 1 , at 54 . 
industrial contexts. For example, sophisticated firms in industries in which there are great returns from new technologies develop a highly variegated structure for the generation of new ideas and their reduction to practice. Such firms support laboratories of research scientists, groups of more applied scientists who work with the results of the theoretical research, other scientists skilled in making the results practicable, and still further individuals who transform the product into something useful for consumers.

Indeed, one might predict that, if the demand for legal services and the benefit from new legal ideas continue to grow, the legal establishment - both the academy and the bar - will be transformed increasingly to resemble the structure of the high-tech industrial firm. Some set of scholars will concentrate principally on theoretical research, while others will work at various levels of application, including the judiciary, which must necessarily operate at a level of broad generality, and practitioners, who apply ideas day to day to the specific problems of their clients.

This description of the structure of the production of ideas suggests that the difference between legal theoreticians and practitioners will continue to grow, but that disjunction or division, which Judge Edwards and I have noted, ${ }^{39}$ misdescribes the relationship. As members of a broader legal establishment, theoreticians, and practitioners have different responsibilities and must refine different skills in order to contribute most effectively to the success of the legal system. But to emphasize disjunction or division - and especially hostile disjunction and division, as Judge Edwards and I have - substantially distorts what is more accurately described as a functionally cooperative relationship. There is no reason to regard the doctor who skillfully diagnoses the disease and prescribes the appropriate pharmaceutical as in some way hostilely divided from the research scientist who first isolated the viragen or the research chemist whose idea generated the drug. They are different individuals, and their talents and skills are surely different. It is similarly misdescriptive to regard legal theoreticians as hostilely divided from practitioners who reduce ideas to practice in order to solve their clients' problems.

There are substantial differences, of course, between the generation of, say, pharmaceuticals and the production of ideas about the law. To a far greater degree, pharmaceutical research as well as the production of intellectual property in other industrial contexts is constrained

39. See generally Edwards, supra note 1; Priest, supra note 3. 
within an economic market. ${ }^{40}$ Undoubtedly, research chemists are afforded some latitude, but continued years without useful discoveries will not be rewarded.

The "market" for legal ideas - especially within the academy is qualitatively different. To describe ideas as subject to a "market" or to "free trade" has become commonplace following Holmes' stirring dissent in Abrams. ${ }^{41}$ The seeming plausibility of the metaphor derives from the characteristics of competition among alternatives, choice by consumers or citizens among those alternatives according to some standard of merit, and, perhaps, from the sense of combative, sometimes distasteful, rigor that many associate with commercial markets. ${ }^{42}$ I believe, however, that the market metaphor is misplaced ${ }^{43}$ because these characteristics are not central to the operation of economic markets. A need for consumers or citizens to choose among sharply competing alternatives is inevitable whenever there are sharply competing alternatives, regardless of the form of economic organization.

Economics, in contrast, views the market as an institution for relaying information concerning consumer or citizen preferences to direct investment and the allocation of resources in order to maximize consumer welfare. Competition among alternatives is an aspect of a market, but far more central are prices as well as the incentives and disincentives that derive from them in influencing productive investment to best benefit consumers.

One can imagine the operation of such an institutional process in the context of the production of commercial intellectual property. Product sales reward individual firms for generating ideas most useful to consumers; presumably the firm appropriately rewards the research scientists within the firm in turn. Thus, research investment is di-

40. Again, this essay is meant only to be suggestive, but a fuller comparison would incorporate the role of academic research in chemistry to the description of research and development in a pharmaceutical firm. If academic chemistry resembles academic law, the industries would appear to differ in that, to my knowledge, there is no institution comparable to the corporate research lab within modern law firms, suggesting a lower degree of specialization within the legal establishment. These questions deserve further study.

41. "[T] he ultimate good desired is better reached by free trade in ideas . . . the best test of truth is the power of the thought to get itself accepted in the competition of the market, and ... truth is the only ground upon which ... wishes safely can be carried out." Abrams v. United States, 250 U.S. 616, 630 (1919) (Holmes, J., dissenting).

42. See, for example, Justice Brennan's definition of "the central meaning of the First Amendment" as the "profound national commitment to the principle that debate on public issues should be uninhibited, robust, and wide-open, and that it may well include vehement, caustic, and sometimes unpleasantly sharp attacks on government and public officials." New York Times Co. v. Sullivan, 376 U.S. 254, 270, 273 (1964).

43. For other, though different, criticisms of the metaphor, see Stanley Ingber, The Marketplace of Ideas: A Legitimizing Myth, 1984 DUKE L.J. 1. 
rected to those ends most valuable to consumers. It is substantially more difficult, however, to identify the exact market analogues with respect to the production of legal ideas or, surely, political ideas - the most common subjects of the metaphor.

Judge Edwards does not address the market for legal ideas directly, though many of his criticisms of the modern academy are related. His repeated description of theoretical research in the law as "impractical scholarship"44 suggests that he sees no marketlike restraint on the legal academy. ${ }^{45}$ Judge Edwards begins his essay by describing his astonishment at the receipt of a letter from a "wellknown law professor," which Judge Edwards interprets as a "frank admission that [the professor] is 'unwilling to redirect' his writing in useful ways, since he prefers to study whatever 'fascinates' him." Judge Edwards compares his correspondent to a "stamp collector[ ]."46 Judge Edwards concludes his discussion of modern legal scholarship by insisting that " '[p]ersonal fascination' is not a sufficient justification for scholarship, of any kind. Insouciant 'pastiches,' which no self-respecting academic journal would publish, have no place in the law reviews." 47

Again, the market for legal ideas is difficult to describe, and much further analysis is needed. In my experience, however, Judge Edwards' views of the legal academy and, in particular, of those who regard themselves as theorists are surely inaccurate in part and probably inaccurate in most respects. There are many examples of economic market forces operating directly on the production of legal scholarship, thus ensuring some level of utility. At the broadest level, the active market within law teaching - the competition among schools for the most promising of legal scholars - suggests that much legal scholarship will be responsive to important legal questions. At a more direct level, the increasing transformation of articles into short books, designed both to attract a different readership and to generate royalties, is suggestive. Similarly, the rise of symposia, in particular,

44. Edwards, supra note 1, at 35, 46-56.

45. I do not wish to mistake Judge Edwards' attitude toward markets from the occasional references in his essay. At other points, he condemns modern law firms for their excessive pursuit of profit. $I d$. at 34,67-74. Pursuit of profit itself may only mean that law firms are increasingly pressing their members to apply their talents toward solving as many client problems as possible, which I would regard as a positive influence of the profit motive. Judge Edwards, however, seems to be criticizing the way in which law firms are garnering profits - through excessive lawyering, overbilling, and unnecessary work - which in economic terms represents market failure, rather than success.

46. Id. at 36. Judge Edwards' interpretation of the letter is surely unfair if his correspondent is, say, fascinated by topics that lead to new thinking about the legal system.

47. Id. at 56. 
symposia that offer their authors honoraria in order to attract discussion of specific subjects illustrates the direct effect of economic incentives. The operation of marketlike forces that influence the direction of scholarly investment is often more subtle, though nonetheless effective. For example, the common phenomenon of waves of articles following controversial Supreme Court decisions surely indicates scholarly responsiveness to relevance. In addition, though the returns may not be directly pecuniary, I know of no authors who are indifferent to readership. The rise of citation counting within the past ten years, surely, reflects a concern for relevance.

Of course, the issue is not simply whether pecuniary returns influence the choice of topics or the reception of ideas. Judge Edwards' criticism is that much of modern legal scholarship, including the portion that regards itself as theoretical, is, in his words, "impractical" divorced from the constraints of utility and relevance to legal issues facing our society. That some part of legal scholarship is responsive to direct economic incentives or the related incentives that stem from academic consulting suggests the limitations of Judge Edwards' claim. I do not believe, however, that direct economic incentives influence much of modern theoretical scholarship. In the legal academy, the forces that influence the choice of research topics and the reception of ideas are substantially more subtle and difficult to define precisely. Nevertheless, the evident costs to an author of producing legal scholarship, even theoretical scholarship, implies the necessary existence of some compensating return and, thus, practicality at some level. Filling in footnotes and editing text are far more tedious than stamp collecting.

Judge Edwards' complaints about the increasing impracticality of much of theoretical research are unfair in a different sense. In no field are there positive returns from every investment in basic research. Indeed, in terms of successful inventions per attempt, the dominant output of research laboratories is probably failure. Theoretical research is a probabilistic process.

Research in legal theory, however, is different from the pharmaceutical example in one important respect. When economic forces constrain research investments, there is likely to be a lower rate of failure than when economic forces are largely absent, as in legal theory. Thus, consistent with Judge Edwards' criticism, there is likely to be a much wider and less fruitful range of theoretical inquiry in the legal academy than in the research department of a high-tech industrial firm. 


\section{Judge Edwards' Reform Proposals Reconsidered}

Judge Edwards proposes to reform legal scholarship and teaching in three ways: First, he hopes to encourage more doctrinal legal scholarship that would provide more practical assistance to the judiciary and the bar, in contrast to "impractical" theoretical or interdisciplinary work. ${ }^{48}$ Second, he hopes to promote more doctrinal teaching defined here to include the legal techniques of using doctrine - to better prepare law students for law practice substantively and in terms of legal skills. Again, this pedagogical policy would imply a shift away from current theoretical or interdisciplinary teaching. ${ }^{49}$ Finally, he wants greater emphasis in the law school curriculum on the preparation of students for "ethical" practice, which means understanding the law as an instrument to promote the public interest and a legal practice consistent with this end. 50

First, at the most basic level, I believe that Judge Edwards' goals are inconsistent. To view law as an instrument to promote the public interest and to study how the legal system can effectuate the public interest is the essence of interdisciplinary work. Interdisciplinary work - especially in the social sciences and philosophy - consists of the study of the effects of law on the citizenry, the values imbedded in the law, and how the public interest may best be achieved. Judge Edwards must acknowledge as much, at least with respect to cases he regards as "very hard." It follows, however, that the broad encouragement and development of Judge Edwards' "ethical" approach to the law require more interdisciplinary study and teaching, rather than less. Again, the focus on accumulated doctrine alone cannot fulfill this ambition. Indeed, it is difficult to believe, given Judge Edwards' highly admirable commitment to public service, ${ }^{51}$ that he would sincerely prefer to substitute the teaching of doctrine for the teaching of societal impact and values.

Second, Judge Edwards' more general preference for shifting the balance of doctrinal versus theoretical scholarship and teaching remains problematic. Judge Edwards is surely correct that much of a student's doctrinal learning occurs after law school, either in preparation for the bar examination or in law firm apprenticeship. ${ }^{52}$ Whether there would be greater returns - more effective practice - from mov-

48. Id. at 42.

49. Id. at 57-66.

50. Id. at 66-74. For Judge Edwards' definition of "ethical" teaching and practice, see supra note 12.

51. See, e.g., Edwards, supra note 12.

52. Edwards, supra note 1, at 57-58. 
ing this apprenticeship more fully back into the law schools is difficult to determine.

Judge Edwards' call for more practical scholarship is equally difficult to evaluate. As we have seen, the issue involves determining the level of specialization that, in economic language, yields the greatest return in terms of legal reform. It is equivalent to a high-tech industrial firm deciding whether it should invest more in basic or applied research. There is no easy answer to the question.

The description here of the broader structure of the legal establishment, however, suggests that the question is not answered - in the way both Judge Edwards and I attempted in the past - by observing the extremes of legal specialization, theoreticians and practitioners; commenting on the growing disjunction or division between them; and encouraging the one we respectively prefer. It is surely more constructive to attempt to understand the reasons for increased specialization and, then, to promote appreciation of the cooperative relationship between the academy and the bar toward the end of improving our system of law. 